Published as: Leterrier Y., Thivolle J., Oliveira F., Månson J.-A.E., Gubler L., Ben youcef H., Bonorand L., Viscoelastic Phase Diagram of Fluorinated and Grafted Polymer Films and Proton Exchange Membranes for Fuel Cell Applications, J. Polym. Sci. B: Polym. Phys., 51, 1139-1148 (2013). DOI 10.1002/polb.23309. () 2013. This manuscript version is made available under the CC-BY-NC-ND 4.0 license http://creativecommons.org/licenses/by-nc-nd/4.0/

\title{
Viscoelastic phase diagram of fluorinated and grafted polymer films and proton exchange membranes for fuel cell applications
}

Yves Leterrier*, Jérémy Thivolle, Fabiane Oliveira and Jan-Anders Månson

Laboratoire de Technologie des Composites et Polymères (LTC)

Ecole Polytechnique Fédérale de Lausanne (EPFL)

CH-1015 Lausanne, Switzerland

Lorenz Gubler, Hicham Ben youcef and Lukas Bonorand

Electrochemistry Laboratory

Paul Scherrer Institut (PSI)

CH-5232 Villigen PSI, Switzerland

(*) corresponding author 


\section{GRAPHICAL TABLE OF CONTENTS}

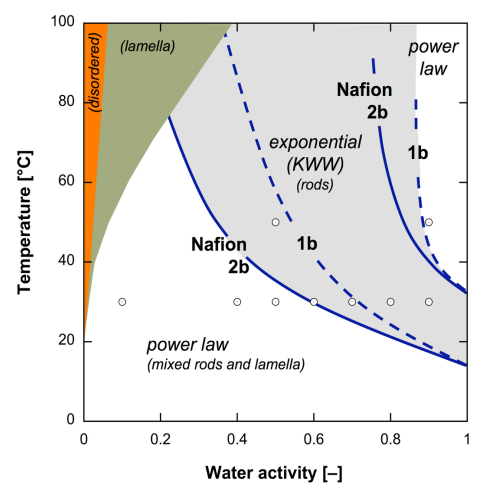

Proton exchange membranes for fuel cell applications were developed based on fluorinated, radiation grafted and crosslinked polymers. These polymers exhibit intricate hygro-thermomechanical properties. A phase diagram was developed to map critical transitions in viscoelastic behavior and investigate the influence of the grafted and crosslinked chemistry on these transitions. 


\section{ABSTRACT}

The influence of temperature and moisture activity on the viscoelastic behavior of fluorinated membranes for fuel cell applications was investigated. Uncrosslinked and crosslinked ETFE based proton-conducting membranes were prepared by radiation grafting and subsequent sulfonation and their behavior was compared with base ETFE film and commercial Nafion ${ }^{\circledR}$ NR212 membrane. Uniaxial tensile tests and stress relaxation tests at controlled temperature and relative humidity $(\mathrm{RH})$ were carried out at $30^{\circ} \mathrm{C}$ and $50^{\circ} \mathrm{C}$ for $10 \%<\mathrm{RH}<90 \%$. Grafted films were stiffer and exhibited stronger strain hardening compared to ETFE. Similarly, both uncrosslinked and crosslinked membranes were stiffer and stronger than Nafion ${ }^{\circledR}$. Yield stress was also found to decrease and moisture sensitivity to increase upon sulfonation. The viscoelastic relaxation of the grafted films was found to obey a power law behavior with exponent equal to $-0.05 \pm 0.01$, a factor of 2 lower than ETFE, weakly influenced by moisture and temperature. Moreover, the grafted films presented a higher hygrothermal stability compared to their membranes counterparts. In the case of membranes a power law behavior at $\mathrm{RH}<60 \%$ was also observed. However, a markedly different behavior was evident at $\mathrm{RH}>$ $60 \%$, with an almost single time exponential relaxation. An exponential decrease of relaxation time with $\mathrm{RH}$, from $60 \mathrm{~s}$ to $10 \mathrm{~s}$ was obtained at $\mathrm{RH} \geq 70 \%$ and $30^{\circ} \mathrm{C}$. The general behavior of grafted films observed at $30^{\circ} \mathrm{C}$ was also obtained at $50^{\circ} \mathrm{C}$. However, an anomalous result was noticed for the membranes, with a higher modulus at $50^{\circ} \mathrm{C}$ compared to $30^{\circ} \mathrm{C}$. This behavior was explained by solvation of the sulfonic acid groups by water absorption creating hydrogen bonding within the clusters. A viscoelastic phase diagram was elaborated to map critical conditions (temperature and relative humidity) for transitions in time-dependent behavior, from power law scaling to exponential scaling.

Key-Words: Proton-exchange membranes; viscoelasticity; water activity; phase diagram 


\section{INTRODUCTION}

Proton-exchange membranes (PEMs) in polymer electrolyte fuel cells (PEFC) are required to exhibit chemical, mechanical, and thermal stability to maintain their functionality as electrolyte and separator for reactant gases and electrons over an operating time of several thousand hours [1]. Whereas the chemical stability of the ionomer is governed mainly by the resistance towards oxidative stress generated by radicals formed as intermediates in the membrane electrode assembly (MEA) [2, 3], the mechanical stability of the polymer is determined by the hygro-thermal and viscoelastic properties of the material [4-6]. The proton conductivity of the PEM is a function of the water uptake of the membrane [7], yet the incorporated water leads, owing to the spatial confinement of the membrane in the cell, to the build-up of internal stresses in the ionomer and viscoelastic flow [6], which can lead to pinhole formation and catastrophic failure of the cell. Therefore, the characterization of the time-dependent behavior of PEMs exposed to mechanical stress under conditions relevant to the application, i.e., elevated temperature and humidity, is of importance for the development of durable membranes for fuel cells.

A widely used class of materials as polymer electrolyte in fuel cells are perfluoroalkylsulfonic acid (PFSA) ionomers, such as Nafion $^{\circledR}$ (Dupont) or Flemion ${ }^{\circledR}$ (Asahi Glass), due to their favorable ratio of proton conductivity and water uptake [8], and their excellent chemical stability towards hydrolysis and radical induced degradation. The mechanical properties of Nafion ${ }^{\circledR}$ have been studied by various authors. Temperature and relative humidity have a large impact on the stress-strain properties of Nafion ${ }^{\circledR}$, with the stress limit for the onset of plastic flow decreasing with humidity and, especially, temperature $[6,9-11]$. This led to the development of constitutive models for PFSA membranes [6, 10]. Furthermore, it was found 
that while PFSA membranes, exposed to water vapor, appear to follow constitutive behavior of a semicrystalline polymer, the response is more elastomer-like when the material is in contact with liquid water [12]. Based on constitutive models including hygrothermal expansion data of PFSA membranes, it was possible to establish finite-element (FE) models to estimate mechanical stress levels in membranes assembled in a cell fixture, i.e., spatially confined membranes, as a result of changes in temperature and humidity $[5,6,13]$. Experimentally, the stress and strain levels in a constrained membrane were measured using a bimaterial strip consisting of PEEK and Nafion ${ }^{\circledR}$. Upon cycling of the relative humidity, both tensile and compressive stresses were measured in the order of a few MPa, as well as mechanical strain levels of around $10 \%$. The hygrothermal aging of the material, as a result of relative humidity cycling, can eventually lead to fatigue-induced failure of the membrane [14]. In this respect, it is important to understand the time-dependent, viscoelastic properties of membranes, which govern their mechanical response over several thousand hours during fuel cell operation. For Nafion ${ }^{\circledR}$, the tensile stress relaxation properties exhibit a complex dependence on temperature, water activity, and strain [15]. Based on creep tests at different temperatures and relative humidities, Lai et al produced a creep compliance master curve for Nafion ${ }^{\circledR}$ NR-111 membranes, highlighting, that the principle of time-temperature-humidity superposition can be applied [14]. Majsztrik et al. analyzed tensile creep of Nafion ${ }^{\circledR}$ N1110 membranes in the temperature range of 25 to $110^{\circ} \mathrm{C}$ and humidity range of 0 to $95 \%$, revealing that small amounts of absorbed water resulted in large changes in the mechanical properties of Nafion ${ }^{\circledR}$ [16]. The role of water is complex and ambiguous: below $40^{\circ} \mathrm{C}$ water plasticizes Nafion ${ }^{\circledR}$, but above $90^{\circ} \mathrm{C}$ it stiffens Nafion ${ }^{\circledR}$, as also concluded by Bauer et al. [17], who further observed, that increasing water activity shifted the $\alpha$-transition of the ionic regions to higher temperatures. The relaxation around $100^{\circ} \mathrm{C}$ to $120^{\circ} \mathrm{C}$ in Nafion ${ }^{\circledR}$ is somewhat debated in the literature. It has been referred to as glass transition by some authors, 
others identified it with a order-disorder (melting) transition of ionic clusters [15]. For a glass transition, one would expect a decrease in the transition temperature to lower values with increasing hydration level of the ionomer, which is not observed [16]. Based on the intricate mechanical response, Majsztrik et al. established a structural phase diagram of $\mathrm{Nafion}^{\circledR}$ comprising different "phases", such as rod-like or lamellar structures.

In view of the commercialization of fuel cells, there is a demand for more cost-effective membranes. The key asset of radiation grafted membranes over other types of partially fluorinated or hydrocarbon polymers considered as PEMs for fuel cells, such as polyarylene membranes (e.g., [18]) or polymer blends [19], is the lack of a film forming process, combined with the use of low cost materials, as well as the ability to adjust membrane parameters (ion exchange capacity, water uptake, flexibility) within a wide range. Semicrystalline fluorinated or partially fluorinated polymer films, such as fluorinated ethylene propylene (FEP), polyvinylidene fluoride (PVDF) or ethylene tetrafluoroethylene (ETFE) are typically used as base polymers for the preparation of radiation grafted membranes for fuel cells. Their chemical and thermal stability and favorable radiation chemistry allows the introduction of radical sites upon exposure to ionizing radiation without significant radiationinduced chain degradation [20]. During the grafting step, a copolymer is grown ("grafted") onto the activated sites of the base polymer via radical polymerization in a monomer solution. Proton exchange sites are typically introduced subsequently through the sulfonation of the grafted film. Radiation grafted membranes based on grafted and sulfonated styrene and $\alpha-$ methylstyrene have shown encouraging performance in the fuel cell, comparable to state-ofthe-art PFSA membranes, and a durability of several thousand hours at a temperature of $80^{\circ} \mathrm{C}$ [21-23]. These materials exhibited also better mechanical stability than Nafion ${ }^{\circledR}$ type structures [24]. 
Numerous studies report the influence of irradiation, grafting, sulfonation and crosslinking on crystallinity, thermal degradation and melting behavior of PEM $[25,26]$. However, there is a general lack of data on the durability and thermo-mechanical stability of these hygrothermally sensitive materials. Whereas composition, functional properties, such as ionic content, water uptake and proton conductivity, performance and durability in the fuel cell have been studied to a considerable extent [25], the investigation of the mechanical properties was thus far limited to experiments carried out under ambient conditions [24]. It is evident that an understanding of the mechanical properties as well as the viscoelastic behavior of radiation grafted membranes under application-relevant conditions, i.e., at elevated temperature and humidity, is key to develop a PEM with high operational stability.

The objective of this work was to determine the stress-strain behavior and stress-relaxation properties of ETFE film, grafted films, and sulfonated membranes under controlled hygrothermal loads. The results are compared to those of Nafion ${ }^{\circledR} 212$ as commercial benchmark. Particular attention was paid to the effect of crosslinking, which is required to enhance the dimensional and chemical stability of radiation grafted membranes [27].

\section{EXPERIMENTAL SECTION}

\subsection{Materials}

An overview of the polymers characterized in this study is given in Figures 1 and 2. The preparation of radiation-grafted membranes involved the three steps of irradiation, grafting and sulfonation. Grafted films and sulfonated membranes, both uncrosslinked and 
crosslinked, were prepared from a $25 \mu \mathrm{m}$ thick ethylene-co-tetrafluoroethylene base film (ETFE, Tefzel LZ-100, DuPont, USA). The ETFE base film was electron beam irradiated (MeV class, Leoni Studer AG, Däniken) to a dose of $1.5 \mathrm{kGy}$ and subsequently stored at $-80^{\circ} \mathrm{C}$ until used. Grafting was carried out at a temperature of $60^{\circ} \mathrm{C}$ in a solution consisting of $20 \%$ (v/v) monomer, 65\% isopropanol (analytical grade; Fisher Scientific), and 15\% water. The monomer was either styrene (purum grade; Fluka) or a 19:1 mixture (v/v) of styrene and divinylbenzene (DVB) as crosslinker [28]. The DVB used was of technical grade ( $~ 80 \%$ DVB, balance 3- and 4-ethylvinylbenzene; Fluka) and contained a mixture of $m$-DVB and $p$ DVB. Thus, uncrosslinked and crosslinked ETFE grafted films were obtained. A graft level, defined as the mass of the grafted component with respect to the mass of the base film, of around $25 \%$ was targeted by adjusting the grafting time accordingly. Sulfonation of the grafted films was carried out in a solution of $2 \%(\mathrm{v} / \mathrm{v})$ chlorosulfonic acid (Fluka) in dichloromethane (Fluka), at room temperature for $5 \mathrm{~h}$, followed by hydrolysis of the sulfonyl chloride groups in deinonized water $(18 \mathrm{M} \Omega \cdot \mathrm{cm})$ at $80^{\circ} \mathrm{C}$ for $8 \mathrm{~h}$.

A state-of-the-art commercial monolithic membrane of $50 \mu \mathrm{m}$ thickness (Nafion ${ }^{\circledR} \mathrm{NR} 212$, Dupont, Fayetteville, NC, USA) was used as received. The properties of all investigated materials are reported in Table 1.
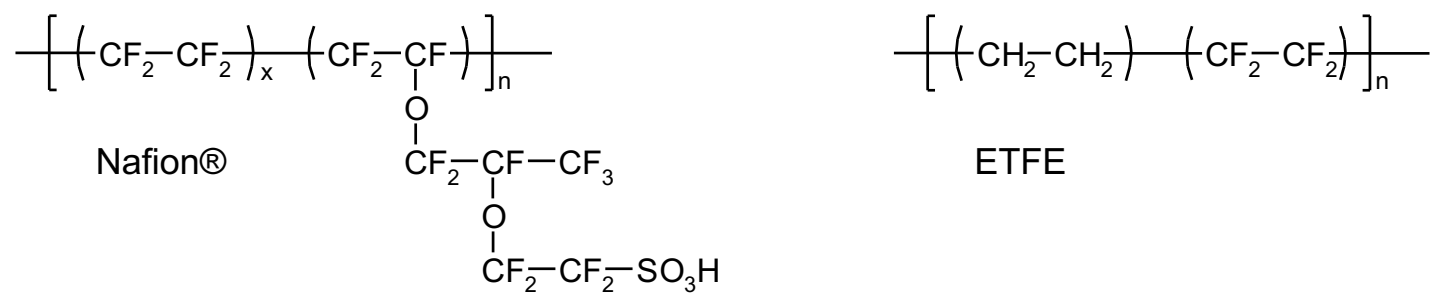

ETFE

Figure 1. Structure of Nafion ${ }^{\circledR}(x \cong 6.5$ for an equivalent weight of 1'100 g/mol) and the ETFE base film used as substrate for radiation grafting. 
<smiles>CC(C)CC(C)c1ccccc1</smiles>

1a: grafted film

1b: membrane

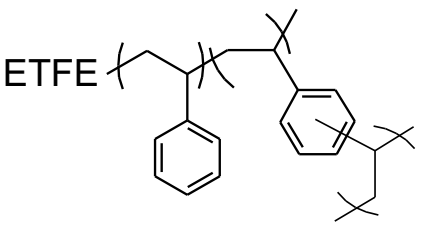

2a: crosslinked grafted film

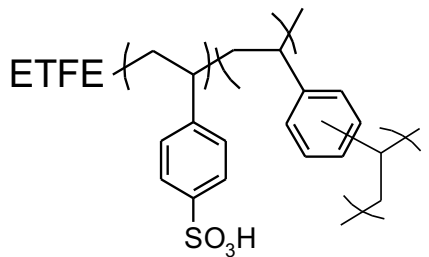

2b: crosslinked membrane

Figure 2. Samples prepared by radiation grafting, using styrene $(1 a, 1 b)$ or a 9:1 v/v mixture of styrene and divinylbenzene (crosslinker) $(2 a, 2 b)$ as grafting monomer. Sulfonation of grafted films (1a, 2a) yields proton conducting membranes (1b, 2b). Sulfonation of the DVB units is unlikely [28].

\subsection{Methods}

The sulfonated membranes were characterized as described in detail elsewhere [29]. The ion exchange capacity was determined via titration and the through-plane proton conductivity was measured at room temperature in water-swollen state using ac impedance spectroscopy. The water uptake was determined based on the difference in mass between the wet and dry membrane.

Differential scanning calorimetry (DSC) measurements were performed on a Perkin-Elmer DSC7 instrument under $\mathrm{N}_{2}$ atmosphere. The base ETFE and the grafted films were measured as prepared, whereas membranes were converted into their salt form by cation exchange in $0.5 \mathrm{M} \mathrm{KCl}$ solution, followed by drying at $50^{\circ} \mathrm{C}$ in the vacuum oven for at least $6 \mathrm{~h}$. Heating runs were performed under $\mathrm{N}_{2}$ at a rate of $20^{\circ} \mathrm{C} / \mathrm{min}$ up to $300^{\circ} \mathrm{C}$. The melting endotherm of ETFE around $265^{\circ} \mathrm{C}$ was integrated to obtain the heat of fusion $\Delta H_{\mathrm{f}}$, from which the crystallinity $\chi$ was determined according to: 


$$
\chi=\Delta H_{\mathrm{f}} / \Delta H_{0}
$$

where $\Delta H_{0}=113.4 \mathrm{~J} / \mathrm{g}$ is the reported heat of fusion for ETFE crystallites. For grafted films and membranes, a correction was applied to account for the dilution of the base polymer by grafted polystyrene and the sulfonic acid group (in salt form), yielding the inherent crystallinity $\chi_{i}$

$$
\begin{aligned}
& \chi_{i}=\frac{\chi}{1+X_{\mathrm{G}}} \text { for grafted films } \\
& \chi_{i}=\frac{\chi}{1+X_{\mathrm{G}} \frac{M\left(\mathrm{St}-\mathrm{SO}_{3} \mathrm{~K}\right)}{M(\mathrm{St})}} \text { for membranes in } \mathrm{K}^{+} \text {-exchanged form }
\end{aligned}
$$

Where $X_{\mathrm{G}}$ is the graft level, $M(\mathrm{St})$ and $M\left(\mathrm{St}_{-} \mathrm{SO}_{3} \mathrm{~K}\right)$ the molar mass of styrene $(104 \mathrm{~g} / \mathrm{mol})$ and potassium styrene sulfonate $(222 \mathrm{~g} / \mathrm{mol})$, respectively.

For mechanical testing, the membranes $1 b$ and $2 b$ were dried in the $\mathrm{H}+$ form (i.e., to reflect the conditions prevalent in a fuel cell), and the other materials (ETFE, grafted films 1a and 2a and Nafion ${ }^{\circledR} 212$ ) were used as received. All the foils were stored for several weeks at room temperature (approximately $23^{\circ} \mathrm{C}$ ) and room humidity (around $60-70 \% \mathrm{RH}$ ) prior to testing.

Tensile tests were performed on rectangular samples cut from the foils along the so-called machine direction. A Linkam TST350 stage equipped with a $200 \mathrm{~N}$ load cell and a temperature and RH controlled chamber was used. The sample gauge dimensions were $11 \mathrm{~mm} \times 12.8 \mathrm{~mm}$ and the strain rate was $310^{-3} \mathrm{~s}^{-1}$. Due to the small sample size, the 
accuracy on the stress values was not very high (approximately $8 \%$ ). The closed-loop temperature control was achieved with a flat heated Ni block enabling a stability of the temperature of $\pm 0.1{ }^{\circ} \mathrm{C}$. The relative humidity was monitored with a chilled-mirror, dew point analyzer (RH200, VTI Corp.) and was stable within $\pm 1 \%$. The tests were done at $30^{\circ} \mathrm{C}$ and at $50 \%, 70 \%$ and $90 \%$ RH. Care was exercised to ensure that samples, once mounted in the chamber of the tensile stage, had reached equilibrium, an essential condition regarding moisture uptake as clearly outlined in [16]. In the work of Majsztrik et al., equilibration times varied from $1^{\prime} 000 \mathrm{~s}$ at temperatures above $90^{\circ} \mathrm{C}$ to $100^{\prime} 000 \mathrm{~s}$ at room temperature for $254 \mu \mathrm{m}$ thick Nafion ${ }^{\circledR}$ foils. It was shown that the water sorption in sulfonated polymers is controlled by interfacial mass transport [30] and scales with membrane thickness (and not with the square of thickness as for Fickian diffusion) [31]. The equilibration time for the $50 \mu \mathrm{m}$ thick Nafion membrane and the $25 \mu \mathrm{m}$ thick membranes $1 \mathrm{~b}$ and $2 \mathrm{~b}$ was therefore estimated to be $20^{\prime} 000 \mathrm{~s}$ and $10^{\prime} 000 \mathrm{~s}$ at room temperature, respectively. In the present work, the samples were conditioned at the selected RH level for $1 \mathrm{~h}$ prior to testing. Some samples were further conditioned for longer times $\left(15 \mathrm{~h}\right.$ or more) at $30^{\circ} \mathrm{C}$, and their properties were found to be similar to those of $1 \mathrm{~h}$ conditioned samples. This means that the moisture concentration in the samples after $1 \mathrm{~h}$ was close enough to the equilibrium value to obtain meaningful results.

Stress relaxation tests were performed using the same stage and same sample type and dimensions as for the tensile tests. Samples were loaded at a rate of $310^{-3} \mathrm{~s}^{-1}$ to a fixed strain $\varepsilon_{0}$ of approximately $1.6 \%$. This strain was well below the yield strain of the films and membranes (around 5\%) and it was assumed to be within the linear viscoelastic domain. The stress $\sigma$ was recorded for a period of $1 \mathrm{~h}$ and the relaxation modulus $E_{r}$ was calculated as the ratio $\sigma / \varepsilon_{0}$. The relaxation time $t_{r}$ included a correction for the loading time $t_{l}$ following the Zapas-Craft approach: $t_{r}=t-t_{l} / 2$, where $t$ is the time with origin $t=0$ at the onset of loading. 
This correction enabled accounting for the relaxation, which occurred during loading [32]. Tests were carried out both at $30^{\circ} \mathrm{C}(10 \%, 40 \%, 50 \%, 60 \%, 70 \%, 80 \%$ and $90 \% \mathrm{RH})$ and at $50^{\circ} \mathrm{C}(50 \%$ and $90 \% \mathrm{RH})$. Samples tested at $30^{\circ} \mathrm{C}$ were conditioned during $1 \mathrm{~h}$ as for the tensile tests. However, it was observed that at $50^{\circ} \mathrm{C}$ the membranes $1 \mathrm{~b}, 2 \mathrm{~b}$ and Nafion ${ }^{\circledR} 212$ had not reached equilibrium after $1 \mathrm{~h}$. These tests samples were thus conditioned overnight for a minimum of $15 \mathrm{~h}$, when their properties had stabilized. Such a large increase of equilibration time with increasing temperature is not understood. It is suggested, that slow structural reorganization processes might occur (case II diffusion), which were not detected at $30^{\circ} \mathrm{C}$. Similar findings were reported by Satterfield and Benziger [16, 31], which these authors ascribed to the clustering of sulfonate groups. Additional investigations (neutron diffraction in-situ [30]) would be needed to clarify this issue.

\section{RESULTS}

\subsection{Process-structure relations}

The materials used for the experimental investigations included the ETFE base film, grafted films and sulfonated membranes, the latter two in uncrosslinked and crosslinked versions. Nafion ${ }^{\circledR} 212$ membranes were used as commercial samples for comparison purposes. The degree of grafting of the materials is reported in Table 1.

Regarding the composition of the crosslinked radiation grafted membrane, it has to be pointed out that the effective ratio of DVB to styrene units in the grafting solution and in the membrane differed due to the different reactivity and, perhaps, diffusivity of the two monomers. We have found, based on FTIR analysis, that in a grafted film, prepared using a 
DVB content of $5 \%$ with respect to the total monomer content in the grafting solution, which corresponds to a molar ratio of DVB to styrene of $4.3 \%$, the average DVB/styrene molar ratio in the graft component was $2.8 \%$ [33]. In a simple estimate neglecting chain branching or crosslinking as a result of chain transfer, this corresponded to a polystyrene chain length of 36 units between crosslink points, which is equivalent to a molecular weight of $3^{\prime} 700 \mathrm{~g} / \mathrm{mol}$, or 6’600 g/mol in the case of styrene sulfonic acid units. However, analysis of surface-near regions of the grafted film using attenuated total reflection (ATR) infrared spectroscopy showed that the extent of crosslinking was more pronounced at the surface, probably because of the higher reactivity of DVB over styrene. For a grafted film prepared with $5 \%$ DVB in the grafting solution, a DVB / styrene ratio of $11 \%$ was measured in the near-surface region [33]. This corresponds to around 9 styrene units between crosslink points.

The influence of grafting and sulfonation on the crystallinity of the ETFE film was investigated using DSC and the results are reported in Table 1. The crystallinity of ETFE film was found to be equal to $33 \%$. Upon grafting the measured crystallinity decreased, primarily as a result of the dilution of the ETFE polymer by the incorporation of the graft component. Yet also the inherent crystallinity of the grafted films, calculated using Equation (2), was found to be lower, albeit slightly, than that of the base film. This can be explained with a loss of crystallinity at the surface of the crystallites as a result of the introduction of the graft component. No significant difference between crosslinked and uncrosslinked films was observed [33]. The inherent crystallinity of the membranes further decreased compared to the grafted films. Probably, the crystallites were partially disrupted because the absorption of water within the hydrophilic domains led to the build-up of mechanical stress at the interface with the crystallites [34]. 
In the context of the application of these polymers as electrolyte membranes in fuel cells, it is of interest to characterize the ion exchange capacity (IEC), i.e., the ionic site density in the ionomer, the degree of swelling in water and the proton conductivity of the membranes. These data are also reported in Table 1 and compared against the Nafion ${ }^{\circledR}$ membrane. The mass based IEC is a typical quantity to measure ionic site density. The ion exchange capacity of the uncrosslinked grafted membrane, adjusted via the graft level while considering that the degree of sulfonation of the styrene units is close to $100 \%$ [28], was chosen such that the conductivity of the membrane in water swollen state is similar to that of $\mathrm{Nafion}^{\circledR} 212$, i.e., around $100 \mathrm{mS} / \mathrm{cm}$. The corresponding IEC of around $1.7 \mathrm{mmol} / \mathrm{g}$ is significantly higher than the IEC of Nafion ${ }^{\circledR} 212$, which is around $1.1 \mathrm{mmol} / \mathrm{g}$. It has to be considered that the densities of the two types of membrane are different. However, even if this is taken into account and the volumetric IEC of the swollen membranes are estimated, the ionic site density in the uncrosslinked radiation grafted membrane is still around $50 \%$ higher than in Nafion ${ }^{\circledR} 212$. For the crosslinked grafted membrane, an IEC value similar to that of the crosslinked membrane was chosen for a meaningful comparison.

The water uptake of Nafion ${ }^{\circledR} 212$ was somewhat higher than that of the uncrosslinked grafted membrane. The comparison of water content is perhaps more meaningful if one determines the volume fraction of absorbed water in the swollen ionomer. The swollen Nafion ${ }^{\circledR} 212$ membrane contains water at a volume fraction of $48 \%$, which is somewhat higher than the $35 \%$ of the uncrosslinked radiation grafted membrane. It is not surprising that the different polymeric materials of Nafion ${ }^{\circledR}$ and styrene grafted and sulfonated ETFE display dissimilar swelling properties. One aspect that may be of importance is that irradiation of ETFE leads to crosslinking reactions [35]. Hence, the nominally "uncrosslinked" radiation grafted membrane may exhibit some degree of crosslinking of the base polymer. In the membrane 
prepared using styrene and DVB as co-monomers the polymer is intentionally crosslinked. The used degree of crosslinking, with a styrene:DVB ratio of 95:5 (v/v) in the grafting solution, is an optimized tradeoff between unfavorable effects at low levels of crosslinking, such as excessive swelling and poor chemical stability in the fuel cell, and adverse effects of brittleness and low conductivity in highly crosslinked membranes [28, 34]. The crosslinking leads to a decrease in the level of hydration, with a water volume fraction of $26 \%$ compared to the $35 \%$ in the uncrosslinked sample, and hence to a lowering of proton conductivity from around $100 \mathrm{mS} / \mathrm{cm}$ to $62 \mathrm{mS} / \mathrm{cm}$. Yet, crosslinking in radiation grafted membranes is essential to obtain chemically and mechanically stable membranes that can operate for thousands of hours in the fuel cell $[21,36]$. The water content of sulfonic acid containing membranes is a governing factor of conductivity. It is perhaps surprising that the uncrosslinked radiation grafted membrane exhibits a similar conductivity compared to Nafion ${ }^{\circledR} 212$ at lower water uptake. It has to be kept in mind, however, that the ion exchange capacity of the radiation grafted membrane is higher, yielding a higher concentration of charge carriers (i.e., protons).

\subsection{Mechanical behavior}

Figure 3 shows the stress-strain behavior of the grafted films and membranes at $30^{\circ} \mathrm{C}$ and at RH levels of $50 \%, 70 \%$ and $90 \%$. In all cases the materials yielded and could be strained beyond $100 \%$ with significant strain hardening. The rather different strain at break values is believed to be an artifact resulting from the sensitivity of film specimens to fracture in presence of small edge defects. Moreover, the apparent greater RH dependence of the behavior of grafted films compared with membranes is due to the relatively high uncertainty $(8 \%)$ on the stress values. Relevant properties are in fact the Young's modulus and the yield stress, reported in Figures 4 and 5, respectively. 


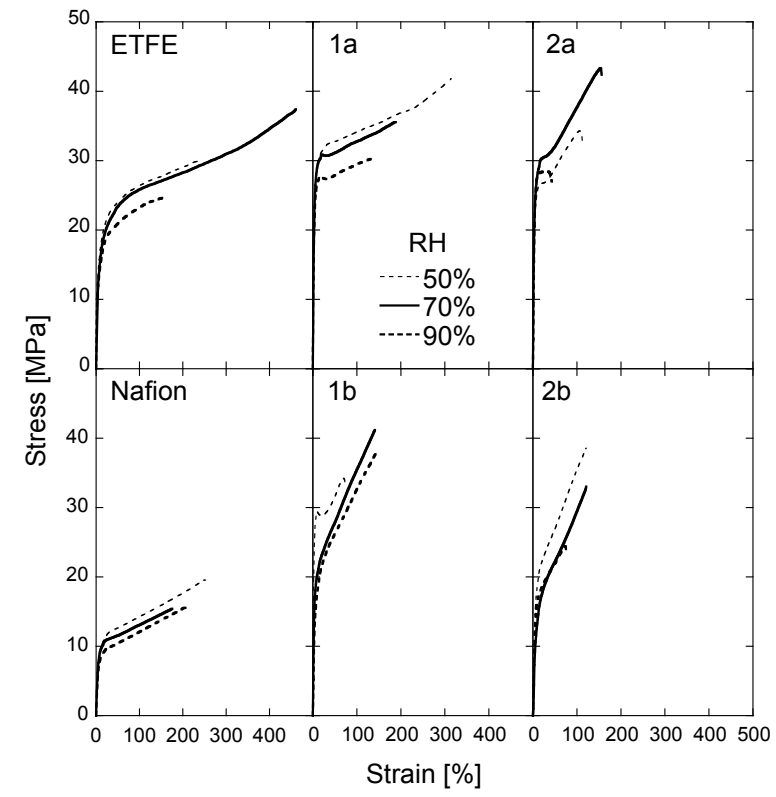

Figure 3. Tensile behavior of ETFE, grafted films $1 \mathrm{a}$ and $2 \mathrm{a}, \mathrm{Nafion}{ }^{\circledR} 212$ and membranes $1 \mathrm{~b}$ and $2 \mathrm{~b}$ at $30^{\circ} \mathrm{C}$ and at $50 \%, 70 \%$ and $90 \%$ relative humidity.

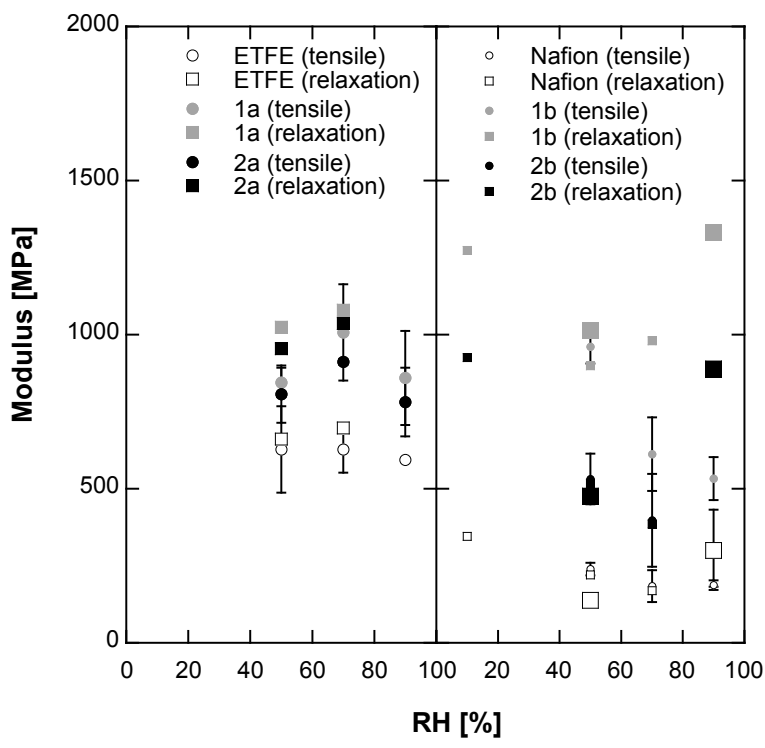

Figure 4. Young's and relaxation moduli of ETFE and grafted films at $30^{\circ} \mathrm{C}$ and of membranes at $30^{\circ} \mathrm{C}(\mathrm{small}$ symbols) and $50^{\circ} \mathrm{C}$ (large symbols) as a function of relative humidity. Standard deviation was available only in the case of repeated tensile tests. 


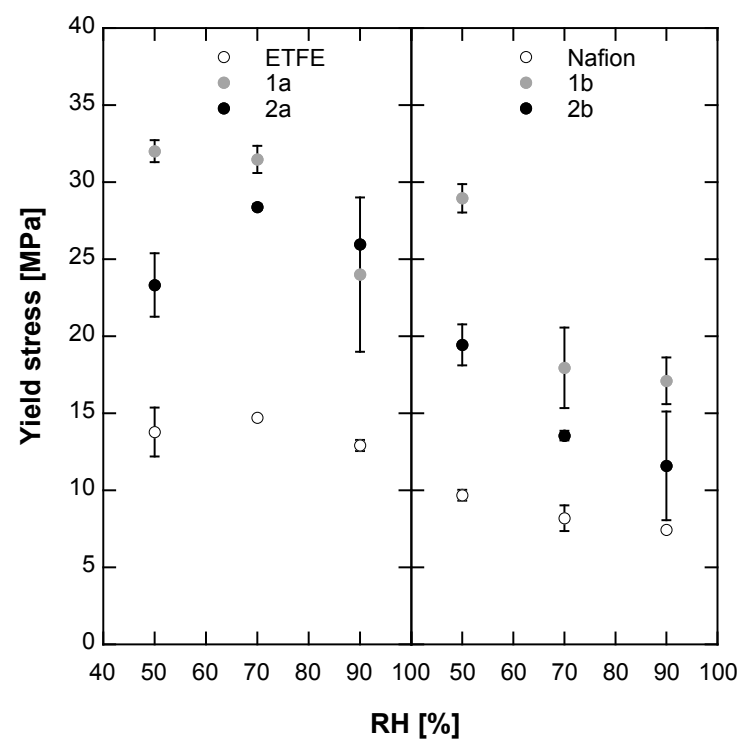

Figure 5. Yield stress of ETFE, grafted films and membranes at $30^{\circ} \mathrm{C}$ as a function of relative humidity.

The Young's modulus of ETFE and both grafted films was close to $600 \mathrm{MPa}$ and $1 \mathrm{GPa}$ at $30^{\circ} \mathrm{C}$, respectively, and independent of $\mathrm{RH}$ within experimental scatter. In contrast, at this temperature the Young's modulus of the membranes decreased considerably with increasing RH, with highest values for membrane $1 \mathrm{~b}$ and lowest values for Nafion ${ }^{\circledR}$. The modulus of the crosslinked membrane $2 \mathrm{~b}$ was significantly lower than that of the uncrosslinked membrane 1b. This result is consistent with the higher inherent crystallinity of the latter membrane. However the water content was also higher in membrane $1 \mathrm{~b}$, which on the contrary should have resulted in a lower modulus. This finding may imply previously reported water stiffening of PEM due to formation of H-bonds within the sulfonic acid group clusters [15]. The initial values of the relaxation modulus $E_{r}\left(t_{r}=t_{1} / 2\right)$ are also displayed in Figure 4 and coincide within scatter with the Young's modulus. At $50^{\circ} \mathrm{C}$ the moduli of the membranes were comparable ( $1 \mathrm{~b}$ and $2 \mathrm{~b}$ ) or lower $\left(\mathrm{Nafion}^{\circledR}\right)$ to the value at $30^{\circ} \mathrm{C}$ and $50 \% \mathrm{RH}$, but were much higher at $90 \% \mathrm{RH}$, particularly for the grafted membranes (i.e., $1330 \mathrm{MPa}$ at $50^{\circ} \mathrm{C}$ vs $500 \mathrm{MPa}$ at $30^{\circ} \mathrm{C}$ for membrane $1 \mathrm{~b}$, and $890 \mathrm{MPa}$ at $50^{\circ} \mathrm{C}$ vs $290 \mathrm{MPa}$ at $30^{\circ} \mathrm{C}$ for membrane 
$2 b)$. This unexpected increase in modulus with increasing temperature at high water activity is discussed in a later section.

Figure 6 regroups the relaxation behavior of all films and membranes at $30^{\circ} \mathrm{C}$ and in the range of $10-90 \% \mathrm{RH}$. The relaxation of ETFE and grafted films in log-log coordinates was almost linear for all investigated RH levels and was described by a power law behavior:

$$
E_{r}\left(t_{r}\right)=E_{r}^{0} t_{r}^{\lambda}
$$

where $E_{r}^{0}$ is the initial modulus, $t_{r}$ is the relaxation time and $\lambda$ is the power law exponent. Such a self-similar relaxation dynamics is typical of elastomers [37], entangled ring-type polymers [38] and nanocomposite suspensions [39]. The influence of moisture on the modulus was rather limited in the case of ETFE, and slightly more pronounced in the case of the grafted films, as already noticed for the Young's modulus. However, in all cases, the relaxation exponent was independent of moisture, as shown in Figure 8. The exponent was equal to $-0.069 \pm 0.009$ for ETFE, approximately $80 \%$ higher than that of the grafted films, equal to $-0.039 \pm 0.006$ for film $1 \mathrm{a}$, and $-0.039 \pm 0.008$ for film $2 \mathrm{a}$. This result confirms the improved viscoelastic stability achieved through the incorporation of aromatic units as part of the grafting process. However no difference was found between film 1a and crosslinked film 2a. 


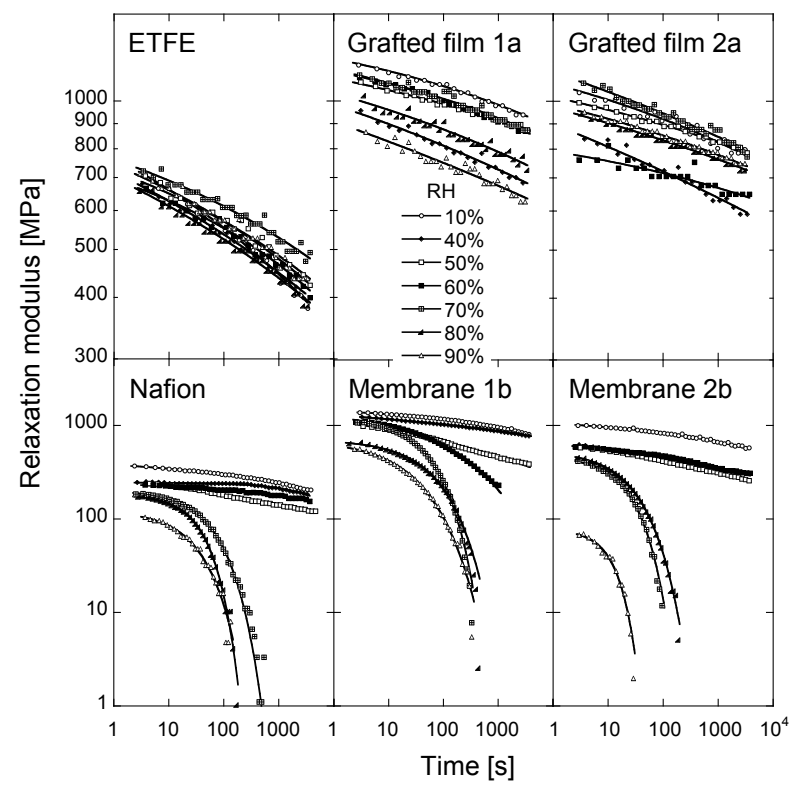

Figure 6. Relaxation modulus of ETFE, grafted films and membranes at $30^{\circ} \mathrm{C}$ and at different relative humidity as indicated (notice the different $y$-scales for the films and membranes).

The relaxation of the membranes was significantly different: a power law behavior was also evident for all three types, but only at RH levels below 50\%. Above 50\% RH the relaxation of the membranes drastically changed to become exponential. These tests also confirmed the stiffness ranking Nafion ${ }^{\circledR}<$ crosslinked membrane $2 b<$ uncrosslinked membrane $1 \mathrm{~b}$. All the data were fitted with a stretched exponential (KWW model [40, 41]):

$$
E_{r}\left(t_{r}\right)=E_{r}^{0} \exp \left\{-\left(\frac{t_{r}}{\tau}\right)^{\beta}\right\}
$$

where $\tau$ is a characteristic relaxation time $\left(E_{r}(\tau)=E_{r}^{0} / e \approx 0.368 E_{r}^{0}\right)$ and the exponent $0<\beta<1$ represents the width of the relaxation time spectrum.

Figure 7 compares the relaxation behavior of the grafted films and membranes at $50 \%$ and $90 \% \mathrm{RH}$, and at $30^{\circ} \mathrm{C}$ and $50^{\circ} \mathrm{C}$. The self-similar behavior of grafted films at $30^{\circ} \mathrm{C}$ (Figures 6 
and $7 \mathrm{a}$ ) was also observed at $50^{\circ} \mathrm{C}(7 \mathrm{~b})$. The anomalous increase of modulus of the membranes with increasing temperature at high water activity is again evident ( $7 \mathrm{c}$ and $7 \mathrm{e})$. Such a behavior is characteristic of polymers above their glass transition temperature $T_{g}$, with a modulus that is proportional to temperature due to entropy effects. In fact, assuming that the $\mathrm{T}_{\mathrm{g}}$ of wet membranes is below $30^{\circ} \mathrm{C}$, only $\sim 7 \%$ of the measured increase of modulus with temperature would be attributed to their rubbery behavior. The measured increase being much more than $7 \%$ other factors must be invoked. Moreover, it invalidates the time-temperature superposition observed in previous works, which is discussed later. The increase of modulus with RH (hence with water activity, $7 \mathrm{~d}$ and $7 \mathrm{e}$ ) can be explained by solvation of the sulfonic acid groups by water absorption creating hydrogen bonding within the clusters [15].

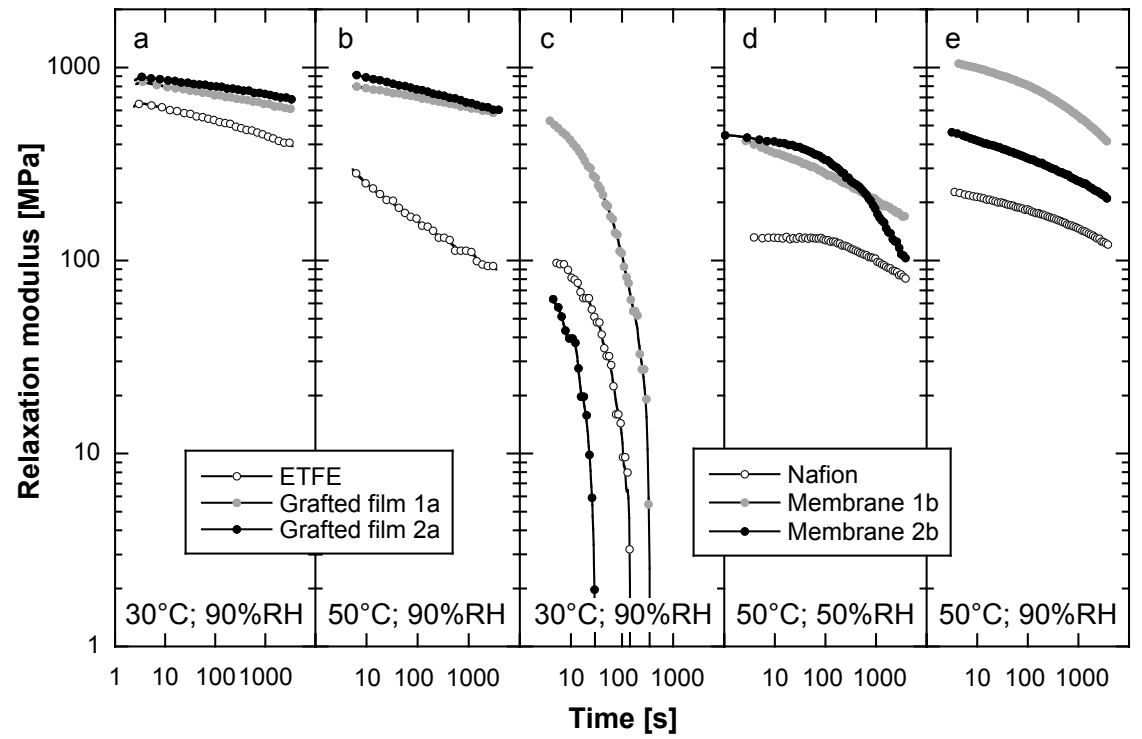

Figure 7. Relaxation modulus of ETFE and grafted films $(a, b)$ and membranes $(c, d, e)$ at various RH levels and temperatures as indicated.

The KWW relaxation parameters of the membranes are also reported in Figure 8 for all investigated $\mathrm{RH}$ levels. At $30^{\circ} \mathrm{C}$ the relaxation time of the three types of membranes was of comparable magnitude with a marked decrease upon increasing RH. It was equal to 
approximately $4 \mathrm{~h}$ at $10 \% \mathrm{RH}$, and to approximately $30 \mathrm{~s}$ at $90 \% \mathrm{RH}$. The values around $50-$ $60 \%$ RH displayed rather large scatter, reflecting a transition in behavior in this humidity range. The exponent also changed with $\mathrm{RH}$ level, being lower than 0.2 at $\mathrm{RH}<50 \%$ (the limit $\beta=0$ corresponds to a power law behavior), and close to 1 at $\mathrm{RH}>60 \%$ (the limit $\beta=1$ corresponds to a single relaxation time process, so-called Maxwell behavior).

The viscoelastic relaxation of the membranes at $50^{\circ} \mathrm{C}$ was quite different compared to $30^{\circ} \mathrm{C}$, especially at $90 \% \mathrm{RH}$, the highest RH level investigated. At $50 \% \mathrm{RH}$ the $\mathrm{Nafion}^{\circledR}$ and crosslinked membranes exhibited an exponential relaxation behavior (Figure 7d) with exponent $\beta$ of approximately $0.4-0.5$. In contrast the relaxation of uncrosslinked membrane $1 \mathrm{~b}$ was still of power-law type, with $\beta \sim 0.1$. At $50^{\circ} \mathrm{C}$ and $90 \% \mathrm{RH}$ the opposite scaling behavior was observed (Figure 7e), with power-law type relaxation for Nafion ${ }^{\circledR}$ and membrane $2 \mathrm{~b}$ $(\beta<0.2)$, and slightly more exponential relaxation for membrane $1 \mathrm{~b}(\beta=0.23)$. These complicated results reflect very specific temperature-dependent interactions between water and the microstructure of the membrane materials, as discussed in the following section. 


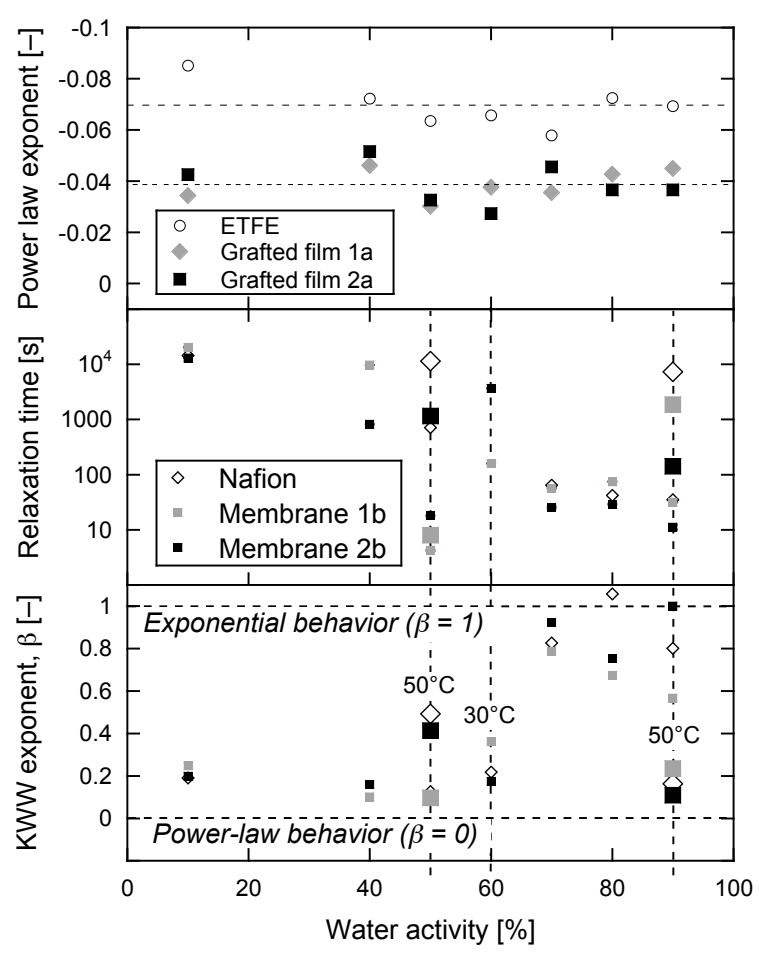

Figure 8. Parameters of the relaxation models at $30^{\circ} \mathrm{C}$ (small symbols for membranes) and at $50^{\circ} \mathrm{C}$ (large symbols for membranes) as a function of water activity: power law exponent $\lambda$ for the relaxation of ETFE and grafted films (Eq. 4, the dotted lines show the average values of $\lambda$ ), and relaxation time $\tau$ and $K W W$ exponent $\beta$ for membranes (Eq. 5, the horizontal dotted lines show the limits for $\beta=0$ and $\beta=1$, and the vertical dotted lines represent the critical $R H$ values at $30^{\circ} \mathrm{C}$ and $50^{\circ} \mathrm{C}$ as indicated).

\section{DISCUSSION}

Figure 9 represents a tentative viscoelastic phase diagram of the investigated PEMs, showing the boundaries between the power-law and exponential relaxation behaviors. This diagram is based on the structural data from the group of Benziger [16], which was elaborated considering local minima in creep strain rate as a function of temperature and $\mathrm{RH}$. The disordered and lamella phases discussed by these authors were not explored in the present work. 
It turns out that the transition from the power-law relaxation to the exponential relaxation correlates with a phase change in the structure of the hydrophilic domains, namely from spherical sulphonic acid clusters to rods (see e.g. Fig. 1 in [42]), characteristic of second order transitions. The relaxation parameter $\beta$ (Equation 5) would thus represent the critical exponent of the transition (continuity of free energy and e.g., relaxation modulus, and its derivative with respect to the state variable $\mathrm{RH}$, and discontinuous second derivative at a critical RH). The transition was found to occur at comparable hygrothermal conditions for Nafion ${ }^{\circledR}$ and membrane $2 b$, and was shifted to higher water activity for membrane $1 b$.

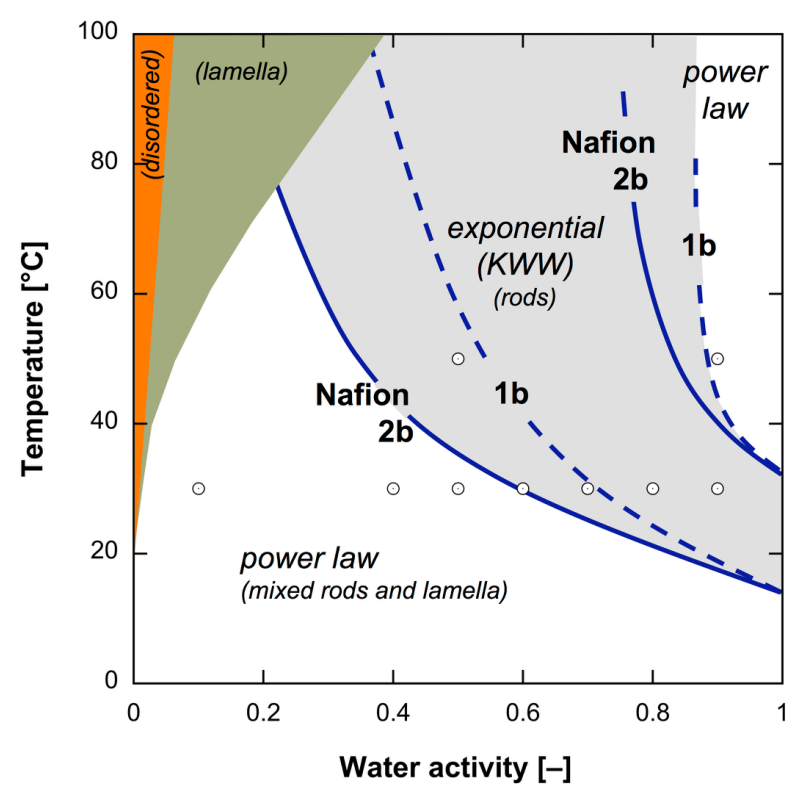

Figure 9. Viscoelastic phase diagram of PEM, with boundaries between power-law and exponential scaling for

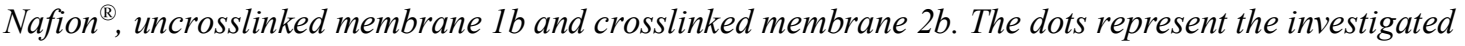
temperatures and relative humidity.

The additional transition, from the exponential to the power-law detected at $50^{\circ} \mathrm{C}$ and $90 \% \mathrm{RH}$ was also shown in the diagram. Again, based on the data from Fig. 8, the transition in behavior of membrane $1 \mathrm{~b}$ appeared to occur at higher water activity compared to Nafion ${ }^{\circledR}$ and membrane $2 \mathrm{~b}$. This second transition would correlate with the large increase of water uptake 
of PEM at very high water activity, as modeled in [42], and with the large increase in time to reach equilibrium at $50^{\circ} \mathrm{C}$ mentioned in Section 3. The increase of modulus of the membranes between $30^{\circ} \mathrm{C}$ and $50^{\circ} \mathrm{C}$ at high $\mathrm{RH}$ (Figures 4 and 7) is also consistent with crossing the transition line. At such high water activity the water uptake, and thus the swelling strain increase with increasing temperature [6,9-11], the latter reaching values as high as 0.2 . The stiffness of the strained membranes would in turn increase, owing to their strain hardening behavior shown in Figure 3. This large swelling phenomenon, combined with the increasing H-bonding within the sulfonic clusters, could explain the observed anomalous stiffening of the membranes with temperature.

It should be pointed out that the boundaries shown in the phase diagram are based on linear viscoelastic relaxation data (applied strain of 1.6\% well below the yield strain of the films and membranes, around 5\%). At higher strain levels (e.g. [43]), nonlinear processes would be activated (viscoelastic and plastic) and these would change the shape of the relaxation spectrum with a reduction of the exponent $\beta$ (see e.g., [44]). Whether this change of relaxation behavior would impact the transitions depicted in Figure 9 is however unlikely since the same transitions were observed beyond yield strain [16]. In other words, the present viscoelastic phase diagram should be valid at high strain levels relevant for fuel cell operation.

As a whole, it was found that the viscoelastic behavior of the crosslinked grafted membrane $2 \mathrm{~b}$ is similar to that of $\mathrm{Nafion}^{\circledR} 212$, whereas the uncrosslinked grafted membrane $1 \mathrm{~b}$ behaves somewhat differently. Based on investigations of the morphology of crosslinked and uncrosslinked grafted films using small-angle scattering techniques, it was established that large-scale structural density fluctuations in the range of $180 \mathrm{~nm}$ develop upon grafting in 
case of uncrosslinked films, whereas in the case of crosslinked films, the structural features of the base film are preserved [45], thereby exhibiting morphological characteristics more similar to those of Nafion ${ }^{\circledR}[46]$.

The observed phase transitions invalidate the principles of time-temperature and timehumidity superposition validated in previous studies for similar fluorinated membranes. Lai et al. reported a creep compliance master curve for Nafion ${ }^{\circledR} 111$ based on measurements carried out over a range of temperature and relative humidity conditions [14], yet the parameter space probed was limited to the 'exponential' area in the phase diagram of Figure 9. Satterfield et al. highlighted time-temperature superposition for sets of measurements in dry and $100 \% \mathrm{RH}$ conditions, which again corresponds to the probing of a single-phase region in the phase diagram [15]. Time-humidity superposition, however, was not obeyed in their work, neither in the present work, owing to the fact that the material undergoes a phase transition in the respective parameter space. This illustrates the complexity of the time-dependent mechanical properties of ion-containing polymers, where the structure and morphology of the ionomer critically depends on the level of hydration. This appears to be the case for Nafion ${ }^{\circledR}$ as well as the grafted membranes.

\section{CONCLUSIONS}

The viscoelastic behavior of uncrosslinked and crosslinked ETFE-based grafted films and proton-conducting membranes at $30^{\circ} \mathrm{C}$ and $50^{\circ} \mathrm{C}$ and at a relative humidity in the range of $10 \%$ to $90 \%$ were investigated and compared to the behavior of the base ETFE film and to a commercial monolytic Nafion ${ }^{\circledR}$ membrane. Grafted films were found to be stiffer and exhibited stronger strain hardening compared to ETFE for all investigated conditions. 
Similarly, both uncrosslinked and crosslinked membranes were stiffer and stronger than Nafion ${ }^{\circledR}$. The yield stress of the materials was also found to decrease and their moisture sensitivity to increase upon sulfonation. The viscoelastic relaxation of the grafted films was found to obey a power law behavior with exponent equal to $-0.05 \pm 0.01$, a factor of 2 lower than ETFE, weakly influenced by moisture and temperature. The grafted films moreover presented a higher hygrothermal stability compared to the membranes.

A viscoelastic phase diagram was elaborated for the membranes to map critical conditions (temperature and relative humidity) in terms of transitions in time-dependent behavior. A first transition from power law scaling to exponential scaling was observed at a critical RH, equal to $60 \%$ at $30^{\circ} \mathrm{C}$, and below $50 \%$ at $50^{\circ} \mathrm{C}$. The exponential regime was of Maxwell-type with a single relaxation time decreasing exponentially from $60 \mathrm{~s}$ to $10 \mathrm{~s}$ with water activity at $\mathrm{RH} \geq$ $70 \%$ and $30^{\circ} \mathrm{C}$. A second transition, from the exponential to the power-law regimes was detected at $50^{\circ} \mathrm{C}$ and $90 \% \mathrm{RH}$ and was attributed to the large water uptake at such a very high water activity. The resulting swelling phenomenon, combined with the formation of H-bonds within the sulphonic clusters was argued to control the measured stiffening of the wet membranes between $30^{\circ} \mathrm{C}$ and $50^{\circ} \mathrm{C}$. The viscoelastic phase behavior of the crosslinked and the Nafion ${ }^{\circledR}$ membranes were similar, whereas it differed for the uncrosslinked membrane. In the latter case the two phase transitions were shifted to a higher water activity, which was related to the presence of large-scale density fluctuations generated during the grafting step. 


\section{ACKNOWLEDGEMENTS}

The authors acknowledge the Nano-Tera initiative of the Swiss National Science Foundation for funding the work. Assistance with stress relaxation experiments by Pia Reichel is gratefully acknowledged.

\section{REFERENCES}

1. M.F. Mathias, R. Makharia, H.A. Gasteiger, J.H. Conley, T.J. Fuller, C.J. Gittleman, S.S. Kocha, D.P. Miller, C.K. Mittelstaedt, T. Xie, S.G. Yan, P.T. Yu, The Electrochemical Society Interface 2005, 14, 24-35.

2. V.O. Mittal, H.R. Kunz, J.M. Fenton, J. Electrochem. Soc. 2007, 154, B652-B656.

3. M. Danilczuk, F.D. Coms, S. Schlick, J. Phys. Chem. B 2009, 113, 8031-8042.

4. X. Huang, R. Solasi, Y. Zou, M. Feshler, K. Reifsnider, D. Condit, S. Burlatsky, T. Madden, J. Polym. Sci. Part B: Polym. Phys. 2006, 44, 2346-2357.

5. A. Kusoglu, A.M. Karlsson, M.H. Santare, S. Cleghorn, W.B. Johnson, J. Power Sources 2007, 170, 345-358.

6. R. Solasi, Y. Zou, X. Huang, K. Reifsnider, D. Condit, J. Power Sources 2007, 167, $366-377$.

7. T.A. Zawodzinski, C. Derouin, S. Radzinski, R.J. Sherman, V.T. Smith, T.E. Springer, S. Gottesfeld, J. Electrochem. Soc. 1993, 140, 1041-1047.

8. K.-D. Kreuer, S.J. Paddison, E. Spohr, M. Schuster, Chem. Rev. 2004, 104, 46374678.

9. Y. Tang, A.M. Karlsson, M.H. Santare, M. Gilbert, S. Cleghorn, W.B. Johnson, Mater. Sci. Eng. A 2006, 425, 297-304. 
10. A. Kusoglu, Y. Tang, M.H. Santare, A.M. Karlsson, S. Cleghorn, W.B. Johnson, J. Fuel Cell Sci. Technol. 2009, 6, 011012-1..8.

11. Y. Li, D.A. Dillard, Y.-H. Lai, S.W. Case, M.W. Ellis, M.K. Budinski, C.S.

Gittleman, J. Electrochem. Soc. 2012, 159, B173-B184.

12. A. Kusoglu, Y. Tang, M. Lugo, A.M. Karlsson, M.H. Santare, S. Cleghorn, W.B. Johnson, J. Power Sources 2010, 195, 483-492.

13. A. Kusoglu, A.M. Karlsson, M.H. Santare, S. Cleghorn, W.B. Johnson, J. Power Sources 2006, 161, 987-996.

14. Y.-H. Lai, C.K. Mittelsteadt, C.S. Gittleman, D.A. Dillard, J. Fuel Cell Sci. Technol. 2009, 6 .

15. M.B. Satterfield, J.B. Benziger, J. Polym. Sci. Part B: Polym. Phys. 2009, 47, 11-24.

16. P.W. Majsztrik, A.B. Bocarsly, J.B. Benziger, Macromolecules 2008, 41, 9849-9862.

17. F. Bauer, S. Denneler, M. Willert-Porada, J. Polym. Sci. Part B: Polym. Phys. 2005, $43,786-795$.

18. B. Bae, K. Miyatake, M. Uchida, H. Uchida, Y. Sakiyama, T. Okanishi, M. Watanabe, ACS Appl. Mater. Interfaces 2011, 3, 2786-2793.

19. T. Zhang, W. He, J. Goldbach, D. Mountz, J. Yi, J. Power Sources 2011, 196, 16871693.

20. M.M. Nasef, E.S.A. Hegazy, Prog. Polym. Sci. 2004, 29, 499-561.

21. L. Gubler, H. Kuhn, T.J. Schmidt, G.G. Scherer, H.P. Brack, K. Simbeck, Fuel Cells 2004, 4, 196-207.

22. L. Gubler, S.A. Gürsel, G.G. Scherer, Fuel Cells 2005, 5, 317-335.

23. L. Gubler, G.G. Scherer, in Polymer Electrolyte Fuel Cell Durability; M. Inaba, T.J. Schmidt, F.N. Büchi, Springer Science+Business Media, New York, 2009, 133-155 
24. H. Ben youcef, S.A. Gürsel, A. Buisson, L. Gubler, A. Wokaun, G.G. Scherer, Fuel Cells 2010, 10, 401-410.

25. L. Gubler, G.G. Scherer, in Handbook of Fuel Cells: Advances in Electrocatalysis, Materials, Diagnostics and Durability, Volumes 5 \& 6; W. Vielstich, H.A. Gasteiger, H. Yokokawa, John Wiley \& Sons Ltd, Chichester, United Kingdom, 2009, Chapter $20,313-321$

26. S.J. Peighambardoust, S. Rowshanzamir, M. Amjadi, Int. J. Hydrogen Energy 2010, $35,9349-9384$.

27. T.J. Schmidt, K. Simbeck, G.G. Scherer, J. Electrochem. Soc. 2005, 152, A93-A97.

28. L. Gubler, H. Ben youcef, S.A. Gürsel, A. Wokaun, G.G. Scherer, J. Electrochem. Soc. 2008, 155, B921-B928.

29. L. Gubler, N. Prost, S.A. Gürsel, G.G. Scherer, Solid State Ionics 2005, 176, 28492860.

30. G. Gebel, S. Lyonnard, H. Mendil-Jakani, A. Morin, J. Phys. Condens. Matter 2011, 23, 234107.

31. M.B. Satterfield, J.B. Benziger, J. Phys. Chem. B 2008, 112, 3693-3704.

32. A. Flory, G.B. McKenna, Mech. Time-Depend. Mater. 2004, 8, 17-37.

33. H. Ben youcef, S.A. Gürsel, A. Wokaun, G.G. Scherer, J. Mem. Sci. 2008, 311, 208215.

34. S.A. Gürsel, J. Schneider, H. Ben youcef, A. Wokaun, G.G. Scherer, J. Appl. Polym. Sci. 2008, 108, 3577-3585.

35. K. Dawes, L.C. Glover, D.A. Vroom, in Physical Properties of Polymers Handbook; J.E. Mark, 2nd edition, Springer Science + Business Meida, New York, 2007, 867-887

36. H. Ben youcef, L. Gubler, T. Yamaki, S. Sawada, A. Wokaun, G.G. Scherer, J. Electrochem. Soc. 2009, 156, B532-B539. 
37. J.G. Curro, P. Pincus, Macromolecules 1983, 16, 559-562.

38. M. Kapnistos, M. Lang, D. Vlassopoulos, W. Pyckhout-Hintzen, D. Richter, D. Cho, T. Chang, M. Rubinstein, Nature Materials 2008, 7, 997-1002.

39. V. Geiser, Y. Leterrier, J.-A.E. Månson, Macromol. 2010, 43, 7705-7712.

40. F. Kohlrausch, Annalen der Physik und Chemie 1866, 128, 207-227.

41. G. Williams, D.C. Watts, Trans. Faraday Soc. 1970, 66, 80-85.

42. G.S. Hwang, M. Kaviany, J.T. Gostick, B. Kientiz, A.Z. Weber, M.H. Kim, Polymer 2011, 52, 2584-2593.

43. Z. Lu, M. Lugo, M.H. Santare, A.M. Karlsson, F.C. Busby, P. Walsh, J. Power Sources 2012, 214, 130-136.

44. P.A. O’Connell, G.B. McKenna, Mech. Time-Depend. Mater. 2002, 6, 207-229.

45. K. Mortensen, U. Gasser, S. Alkan_Gürsel, G.G. Scherer, J. Polym. Sci. Part B: Polym. Phys. 2008, 46, 1660-1668.

46. G. Gebel, O. Diat, Fuel Cells 2005, 5, 261-276.

47. S. Balog, U. Gasser, K. Mortensen, H. Ben youcef, L. Gubler, G.G. Scherer, Polymer 2012, 53, 175-182.

48. J. Lin, P.-H. Wu, R. Wycisk, P.N. Pintauro, ECS Transactions 2008, 16, 1195-1204.

49. Z. Cai, L. Li, L. Su, Y. Zhang, Electrochem. Commun. 2012, 14, 9-12. 
Table 1. Structure and property data for ETFE, grafted films and proton-exchange membranes. The graft component refers to the composition of the grafting solution $\left(\mathrm{DVB}=\right.$ divinylbenzene). The inherent crystallinity $\chi_{i}$ indicates the effective crystallinity of the original ETFE film. The water uptake in the swollen polymers was measured at room temperature (wt\%) and calculated (vol\%) according to Balog et al. [47]. The conductivity was measured in water swollen state at room temperature.

\begin{tabular}{|c|c|c|c|c|c|c|}
\hline Material & Graft component & $\begin{array}{l}\text { Ion exchange } \\
\text { capacity } \\
\text { (mmol/g) }\end{array}$ & $\begin{array}{c}\text { Crystallinity } \chi \\
(\%)\end{array}$ & $\begin{array}{c}\text { Inherent } \\
\text { crystallinity } \chi_{i} \\
(\%)\end{array}$ & $\begin{array}{l}\text { Water uptake } \\
\text { (wt\% / vol } \%)\end{array}$ & $\begin{array}{l}\text { Conductivity } \\
\text { (mS/cm) }\end{array}$ \\
\hline ETFE base film & - & - & \multicolumn{2}{|c|}{$33.0 \pm 1.2$} & & - \\
\hline Grafted film 1a & styrene & - & $27.4 \pm 0.4$ & $31.1 \pm 0.5$ & & - \\
\hline Membrane $1 b$ & styrene & $1.74 \pm 0.06$ & $17.6 \pm 0.9$ & $26.7 \pm 1.4$ & $34 \pm 3 / 35 \pm 2$ & $102 \pm 13$ \\
\hline Grafted film 2a (XL) & styrene / 5\% DVB & - & $24.7 \pm 1.2$ & $31.2 \pm 1.5$ & & - \\
\hline Membrane $2 b(\mathrm{XL})$ & styrene / 5\% DVB & $1.74 \pm 0.08$ & $15.3 \pm 0.9$ & $23.7 \pm 1.4$ & $22 \pm 3 / 26 \pm 3$ & $62 \pm 2$ \\
\hline Nafion $^{\circledR} 212$ & & $1.08 \pm 0.01$ & $\begin{array}{l}13.6[48] \\
16.4[49]\end{array}$ & & $42 \pm 1 / 48 \pm 1$ & $97 \pm 15$ \\
\hline
\end{tabular}

